\title{
Nad knihou Jana Svobody: Masarykův realismus a filosofie pozitivismu
}

\section{Otakar A. Funda}

Ještě než se rozběhne jubilejní rok vzniku Československé republiky, který nesporně zavdá podnět i $\mathrm{k}$ řadě masarykovských studií, položil ve Filosofickém ústavu AV na stůl novou monografii, věnovanou Masarykovu realismu a filosofii pozitivismu, PhDr. Ing. Jan Svoboda, Ph.D. Kniha vyšla v nakladatelství Filosofia, Praha 2017, 319 stran.

Po slovech uznání, že se ve střední generaci objevil další badatel, který se stará o to, aby téma myšlení TGM nezapadlo a jeho štafeta byla přenesena do přiští generace, nemůže recenzent Svobodovy knihy obejít otázku, v čem je její novost, kromě toho, že po určitém časovém odstupu znovu uchopila jedno $\mathrm{z}$ velkých témat české filosofie a že to učinila s úctyhodnou akribií jak faktografického detailního zvládnutí, tak dokladováním rozsáhlým kritickým aparátem, který je zpracován s důkladností a dle současných norem, jak to $\mathrm{v}$ dř́ivějších generacích ještě nebylo požadavkem ani pravidlem. Nicméně orientaci v Masarykových textech i v Svobodově rozsáhlém kritickém aparátu by zjednodušilo, kdyby na závěr knihy oddělil Masarykovy texty z celkového soupisu literatury, označil je jako prameny a k jejich poslednímu, většinou již kritickému vydání předeslal i údaj prvního vydání.

Mnoho dřívějších badatelů upozorňovalo na různost momentů Masarykova myslitelského díla - motivy platónsko-kantovské, motivy křestansko-teistické, motivy pozitivistické. Někteří si přivlast- nili jeden $\mathrm{z}$ těchto motivů, aby se $\mathrm{v}$ tomto směru považovali za dědice Masarykova odkazu. Patočka naopak tuto polaritu odlišných motivů označil za Masarykovu filosofickou slabost a rozpolcenost. Milan Machovec se pokusil tuto polaritu překlenout tezí, že Masarykovo myšlení je hluboce intuitivním položením klíčových otázek, které teprve další proudy $\mathrm{v}$ evropské filosofii a teologii rozvíjely a domýšlely. Měl za to, že Masarykovu sociální humanitu dále rozvíjela frankfurtská škola, Masarykovo náboženské myšlení bez dogmat a zázraků že rozvíjel projekt demytologizace a existenciální interpretace křestanské víry německého protestantského teologa R. Bultmanna a jeho žáků a Masarykovu otázku po smyslu lidského života a hlubokých dimenzích lidství že dále rozvíjeli existencialisté. Já jsem si dovolil k tomu doplnit, že Masarykův důraz na kriticismus dále rozvíjel Popperův kritický racionalismus, k čemuž se Popper př̀i své návštěvě Prahy hned v první větě svého projevu v aule UK vrátil a tuto indicii potvrdil.

Považuji za vhodné upozornit, aby čtenář Svobodovy knihy měl stále na zřeteli její nadpis a tím i tematické zadání: Masarykĩv realismus a filosofie pozitivis$m u$. Autor si tedy neklade za cíl monograficky zpracovat všechny komponenty Masarykova myšlení během různých fází jeho celoživotní dráhy a podat celistvý obraz Masarykova myšlenkového portrétu, i když motivům platónským věnuje 
dosti pozornosti a Masarykovo náboženské myšlení též uvádí, ale pochopitelně vzhledem $\mathrm{k}$ vymezení tématu je detailněji nerozebírá. Nepozitivistickým motivưm a komponentám Masarykova myšlení věnuje tedy Svoboda pozornost jen potud, pokud vzhledem ke svému tématu potřebuje podtrhnout, $\mathrm{v}$ čem se Masaryk od pozitivismu odlišoval.

Svoboda se zaměřuje především na vyhodnocení motivů A. Comta, D. Humea, J. S. Milla, neméně pak F. Brentana v Masarykově myšlení, právě tak jako i Masarykových jemných, leč závažných diferencí od těchto myslitelů. Přínos knihy tkví především v tom, že v navázání na mnohé badatele, kteří se zabývali Masarykovým vztahem $\mathrm{k}$ pozitivismu a vlivem pozitivismu na Masaryka (zejména F. Krejčí, J. Tvrdý, J. Král, F. Fajfr, Vasil K. Škrach, J. L. Fišer, M. Novák, L. Nový, J. Zumr, M. Havelka, M. Dokulil, J. Gabriel, J. Zouhar, H. Pavlincová, M. Bednář, J. Šebestík, J. Olšovský, Z. Novotný a další) a při zohlednění závažných studií Vl. Hály, věnovaných $F$. Brentanovi a otázkám založení etiky, tuto problematiku nejen znovu otevřela, nýbrž podrobným rozborem podkladů ukazuje na jemné nuance proměn a posunů Masarykova stanoviska i na určitou rozdílnost jednotlivých jeho vyjádření. I když Masarykova myšlenková cesta se vyznačuje značnou konsistencí a nelze mluvit o dramatických předělech či zvratech, přec to není cesta statická a lze na ní vyznačit určité posuny akcentů. Jejich vysledování je ovšem značně náročné. To platí jak o Masarykovu vztahu $\mathrm{k}$ pozitivismu, tak můžeme něco podobného říci o Masarykovu vztahu k náboženství. I když kniha není napsána složitým způsobem, není její četba vůbec snadná. Předpokládá značnou zapracovanost do příběhu Masarykovy myšlenkové cesty. Jen tak může čtenář rozpoznat Svobodou vyznačené jemné i zásadnější posuny a předěly na této cestě.

Vlastní monografii o Masarykovu realismu a jeho vztahu k pozitivismu předesílá Svoboda krátkou rekapitulaci filosofie Augusta Comta, ve které po výkladu o pojetí sociální statiky a sociální dynamiky si všímá obratu v Comtově „vidění skutečnosti“ směrem k vizi "pozitivního náboženstvi“ - „žít pro druhého, láska jako princip, pořádek jako základ, pokrok jako cíl“. (s. 37) Navozuje tak bezděčně u čtenáře otázku, nakolik Comtův pozitivismus svým všelidským universalismem a nárokem poskytnout řešení všech problémů nově vzniklé průmyslové společnosti a směřovat ji $\mathrm{k}$ happy endu lidských dějin vlastně patři do sféry evropského mesiánského historismu - (i když řešení nespatřuje v revoluci, nýbrž ve vědecké transformaci společnosti) - kulturního imperialismu a exportu jedné „pravé civilizace“.

Autor sleduje T. G. Masaryka od jeho prvních, ještě studentských textů. Masarykův způsob čtení i interpretace Platóna byl poněkud osobitý, řekněme svérázný, poplatný ovšem tehdy nejvíce běžnému způsobu recepce Platónovy filosofie. Nad některou formulací se lze ve Svobodově pojednání pozastavit. Jako např., když na s. 91 mluví o Masarykově prvotině „Plató jako vlastenec“, otištěné v almanachu Zora 1877, a poví: „Lze konstatovat, že již v této prvotině Masaryk vystupuje jako zralý sociolog a politik", i když ví o Masarykově problematickém uchopení 
Platónova konceptu a na s. 82-83 v poznámce 131 uvádí Brentanovo značně kritické hodnocení Masarykovy disertace, psané jen o rok dříve a věnované Platónově nauce o duši, jako práce „velmi nedokonalé“.

Autor dokládá, že a jak o empirismu a pozitivismu, o Humeovi, Comtovi a Millovi uslyšel Masaryk již mnohé od svých vídeňských učitelů, od Zimmermanna, Gomperze a Brentana, kteří byli $\mathrm{s}$ touto filosofií v poměrně úzkém kontaktu. Sleduje závažné rozdíly mezi Franzem Brentanem a pozitivismem, kterými Brentano Masaryka výrazně ovlivnil. Zejména Brentanův důraz na psychologii, na lidskou subjektivitu, jeho teistické tázání po příčině a smyslu, jsou v utváření Masarykovy vlastní koncepce realismu výrazné a vyznačují jeho odlišnosti od pozitivismu.

Těžisko práce tkví ve třetí kapitole. Svoboda se zaměřuje na rozbor Masarykových prací z osmdesátých let, na Počet pravděpodobnosti a Humova skepse, Blaise Pascal, jeho život a filosofie a především na Základové konkretné logiky (dále jen Konkrétná logika) a na Masarykovy články v Athenaeu.

Na výkladu o Masarykově pokusu překonat Humeovu skepsi především Mendelssohnovými a Laplaceovými vzorci o počtu pravděpodobnosti (s. 127-128) či Benekeho pokusem (s. 126) oceníme, že Svoboda - v návaznosti na Jana Šebestíka a Zdeňka Novotného i na vlastní Masarykovo přiznání Adolfu Fickovi - nechává otevřený prostor otázkám, nakolik Masarykovo pochopení Humea bylo zcela adekvátní (s. 128-130). Závažné je i upozornění, že Masaryk nereflektuje Brentanovy výklady o počtu pravděpodobnosti, což na Masarykovu adresu vyvolalo kritiku Antona Martyho a Carla Stumpfa, i když sám Brentano mírnil její ostří. Nahlédneme-li jen do Mouralových studií věnovaných Humeovi či do studií uveřejněných ve Filosofickém časopise 2/2017, je zřejmé, že současná debata o interpretaci Humea probíhá v poněkud jiných souřadnicích, než jak své vyrovnání s Humem koncipoval Masaryk. Pro dějiny filosofie má ovšem nahlédnutí do Masarykova pokusu svoji závažnost.

Jen měsíc po přednášce o Humeovi předstupuje Masaryk před pražskou filosofickou veřejnost s přednáškou namírenou - dle Masarykova vlastního vyjádření - proti „ztuchlému liberalismu“ tehdejších pražských intelektuálů (s. 135), v níž představuje život a filosofii B. Pascala. Postrádáme Masarykovo bližší upřesnění, co a koho tímto „ztuchlým liberalismem“ myslil. Mezi řádky Svobodova výkladu o Masarykově pokusu uchopit Pascalovo dilema rozumu a víry rozpoznáváme jeho bolestnou nedořešenost i u Masaryka samého. Masarykovy pozdější výroky, že náboženství je záležitost citu, že náboženství je třeba žít, prozrazují určité pascalovské reminiscence a zároveň stojí v určitém napětí vůči Masarykově racionální argumentaci ve prospěch oprávněnosti teismu jako rozumné a racionálně argumentovatelné hypotézy. Dovolím si jen dopovědět, že v dopise markýzi de Meré, označovaném jako „argument sázky“, sestoupil ovšem i sám Pascal z výšiny svého existenciálního paradoxu víry a uchýlil se $\mathrm{k}$ racionálně až utilitární argumentaci, a přestože Masaryk jde cestou racionálního teismu, nikoli existenciálního paradoxu, spojuje 
jej nakonec s Pascalem to, co na adresu mnoha, zejména katolických teologů, např. Hanse Künga, označil Leszek Kołakowski jako „radikale Erpressung“, jako falešné postavení alternativy: „bud' Bůh, nebo nicota“, u Masaryka: „Bůh, nebo se pověsit na hřebík“.

Ve svém výkladu o Masarykově Konkrétné logice Svoboda neuhýbá př̀ed již mnohokrát diskutovanou otázkou, nakolik je toto dílo jen více méně nepatrně pozměněnou recepcí díla Comtova. Svoboda upozorňuje, jak pozdější Masarykovy návraty $\mathrm{k}$ tomuto tématu a jeho korekce dokládají, jakou závažnost mu přikládal.

$\mathrm{V}$ pojednání o Masarykem i později zamýšlených přepracováních verzí Konkrétné logiky i o jeho reakcích na velkou řadu zahraničních i domácích recenzí lze sledovat, $\mathrm{v}$ jakém smyslu pracuje s pojmem metafyzika, když mluví o „metafyzice empirické a induktivní“ (s. 153), což byl obrat již tehdy kritikou diskutovaný, i kterak si vzhledem $\mathrm{k}$ rozvoji nových vědních oborů přestavoval schéma jejich uspořádání.

Záslužný je Svobodův výklad o Masarykových článcích v různých rubrikách Athenaea. Toto odborné i popularizačně vědní Masarykovo působení, které vyžadovalo námahu sotva představitelnou, bylo výrazem jeho přesvědčení o politice osvětové, o politice založené na vzdělanosti. $\mathrm{V}$ tom můžeme spatřovat silný, Masarykem ne vždy přiznaný ohlas osvícenství a liberálně intelektuální komponentu $\mathrm{v}$ jeho myšlení a politické praxi.

Ve 4. kapitole Svoboda ukazuje, s odvoláním především na práce J. Zumra, I. Tretery a dalších, že český herbartismus zdaleka nebyl strnulý filosofický útvar, od něhož by se Masaryk výrazně distancoval, nýbrž že pozitivismus tematizovali již pozoruhodní čeští herbartovci. Čte tedy Svoboda Masaryka zasazeného do jeho dobově filosofického kontextu a ulamuje hrot některým dřive zvýrazňovaným, až jakoby konfliktním protikladům.

Ve finále knihy, kapitolách 5, 6, 7 - pak autor předkládá svoji základní tezi, že Masarykovou filosofí́ je v podstatě etika jako životní postoj „pod zorným úhlem věčnosti“, znovu uchopuje klíčové momenty Masarykova realismu a shrnuje Masarykovo vlastní pojetí pozitivismu.

Masaryk, poví Svoboda (s. 269 an.), se od Comta liší určením samého pojmu filosofie. Filosofie, vybudovaná na poznatcích moderních věd, je pro Masaryka světonázorovým ukotvením, které přechází v životní postoj rozumnosti a vrcholí v řešení praktických otázek, tedy v etice. Etikou nemyslí Masaryk jen analýzu problémových situací a založení etické argumentace, ale prrímo poskytování návodů správného jednání. Proto už v souvislosti s tematizací věd praktických (s. 150 an.) a především pak právě $\mathrm{s}$ Masarykovým pojetím „reálné“ etiky (kap. 5) Svoboda vyznačuje existenciální dimenzi Konkrétné logiky, jež je v tomto díle podstatně přítomná, tj. onu sféru životního i náboženského ukotvení člověka. Tím současně otevírá otázku po původnosti nutných životních účelů, potažmo i „vy̌šíích“ mravních cílů jakožto jejích principiálních projevů určujících naše postoje a jednání.

O Masarykově etice pojednává Svoboda nejen na základě rozboru jeho univerzitních přednášek z roku 1898/1899, ale $\mathrm{s}$ přihlédnutím $\mathrm{k}$ jeho vyjádřením $\mathrm{v}$ celém pozdějším díle. Upozorňuje na Masaryko- 
vo propojení psychologie a etiky a svůj výklad vyústuje do Masarykova i svého přesvědčení, že člověk je mravně odpovědnou bytostí a že „život a celý svět má smysl mravní“ (s. 245). I když Masaryk nesdílel klasickou křestanskou nauku o zjeveném náboženství a její dogmatiku, poví Svoboda výstižně: „Cit zbožnosti (ve smyslu oné trvale prožívané lásky k bližnímu, jež mu Boha ve skutečnosti zpř́ítomňuje)“, znamená, řečeno s Masarykem: „věčný život je už ted', aneb ho vůbec není “ (s. 254). V př́padě, že byste nečetli hned knihu celou, prostudujte nejprve stránky 239-286.

Protože předávání a šíření vzdělanosti spočívá především $\mathrm{v}$ tradování tradic a protože naše vlastní filosofické tázání, jež vede nejen ke kultivaci osobního života, ale i ke zkvalitnění života politického, je založeno na znalosti dějin a především dějin myšlení, je každá práce jemu věnovaná záslužným počinem. To platí i o dějinách filosofického myšlení v Čechách, či v někdejším středoevropském prostoru vymezeném Habsburskou monarchií. Přicházíme ze svých dějin a dějiny nás vtahuji do svých dějin. Poponášíme své dějinné vědomí a snad $k$ němu něco málo i přičiníme. I když sdílím Popperovu a Albertovu kritiku historicismu, který zejména v 19. století nejednou redukoval univerzitní výuku na dějiny problému, bez dějinného vědomí a znalosti dějin lidského myšlení nastává soumrak vzdělanosti, soumrak kultury i politické kultury a nastupuje, jak pověděl K. Liessmann, zhoubná teorie nevzdělanosti. Proto je každá na studiu podkladů založená práce $\mathrm{k}$ dějinám filosofie počinem, jehož význam a smysluplnost není třeba dále zdůvodňovat.
Pověděno s Hansem Albertem: Naše poznání i jednání je principiálně omylné, tj. převážná většina našich poznatků jsou jen provizorní hypotézy, následně se prokáží jako omyly, a totéž lze říci o většině našich dobře míněných rozhodnutích. To jistě lze vztáhnout i na myšlení a politické dílo T. G. Masaryka. Nicméně přes to, či právě proto, je náš život ustavičným řešením problémů, které nelze vzdát. Fragmentárnost a ambivalence je náš úděl. A unést svou fragmentárnost a ambivalenci znamená unést své lidství. Svobodova kniha o Masarykově realismu jako konceptu, který integruje jak pozitivistický důraz na vědeckost a odbornost, tak otázky po smyslu lidského života a dějin, tak roli subjektu i potřebu metafyzického zakotvení etických principů, nám znovu aktualizuje bázi, na níž bylo založeno Masarykovo řešení problémů.

Na závěr si dovolím příměr: Masaryk mi připomíná varhaníka, který při různých koncertech zapne různé a odlišné rejstř́íky. Posluchači se pak ptají: „Jak to, vždyt před týdnem to hrál jinak?“ Kdo do Masarykova myšlení nahlédl, chápe, že to není ani eklektismus, ani rozpolcenost, ale - při vší zranitelnosti a nedostatcích - úsilí integrovat do sjednocujícího politického programu různé pozitivní komponenty. A o sjednocující pozitivní program, povznášející společnost na základě komplementární vzdělanosti a vědeckosti, šlo přece pozitivistům, Comtovi i jemu blízkému i zároveň vzdálenému Masarykovi.

Osobně se domnívám, že pozitivismus a jeho odkaz není v českém myšlení odložená obnošená vesta. Právě Masaryk nám ukázal, že pozitivismus není mravně 
indiferentní, že pozitivně prokázaná ob- i kvalit a hluboce lidských dimenzí. Skujektivní zjištění mají vždy morální dosah tečný pozitiv nám nepodává jen deskrip- viz Rukopisy, Hilsneriáda, Friedjungův ci, kde leží kámen, kde stojí strom, ale proces. Masaryk předjímal to, co pro sebe sděluje nám něco z „ducha“, z „kvality“ označuji termínem „kvalitativní pozitivis- i podivuhodnosti té krajiny. mus“, tedy nejen pozitivismus kvantit, ale

prof. ThDr. Otakar A. Funda, Dr. Théol. / ofunda@kfi.zcu.cz

Katedra filozofie, Fakulta filozofická, Západočeská univerzita, Plzeň, Česká republika 